Vol. VI-2, Agustus 2010

\title{
SEDIMEN LARUT DALAM ASAM DAN TIDAK LARUT DALAM ASAM DI PERAIRAN TELUK BUYAT DAN SEKITARNYA
}

\author{
Hermanto W.K. Manengkey \\ Staf Pengajar pada Program Studi IImu Kelautan \\ Fakultas Perikanan dan IImu Kelautan. UNSRAT. Manado 95115.
}

\begin{abstract}
Information on water conditions, such as sedimentation, physical factors, and coral reef ecosystem, needs to be understood that the stakeholders could optimally utilize the the area. This study was aimed at determining the sediment content of Buyat Bay and its surroundings dissolved and undissolved in the acid solution. Results found that the terrestrial sediments (Lithogenous) were not soluble in the acid solution and the marine ones (Biogenous) were soluble.
\end{abstract}

Keywords: Sediment, coral reef ecosystem, acid, Buyat Bay.

\section{PENDAHULUAN}

Pembangunan yang merupakan suatu proses perubahan untuk meningkatkan taraf hidup manusia tidak terlepas dari aktivitas pemanfaatan sumberdaya alam. $\mathrm{Di}$ dalam aktivitas ini sering dilakukan perubahan-perubahan pada sumberdaya alam. Perubahan-perubahan yang dilakukan tentunya akan memberikan pengaruh pada lingkungan hidup. Oleh karena itu, dalam perencanaan pembangunan pada sistem ekologi yang berimplikasi pada perencanaan penggunaan sumberdaya alam, perlu diperhatikan kaidah-kaidah ekologis yang berlaku untuk mengurangi akibat-akibat negatif yang merugikan bagi kelangsungan pembangunan itu sendiri secara menyeluruh (Bengen, 2000).

Sebagian besar perairan Buyat memiliki dasar laut berupa pelapisan sedimen yang terbentuk akibat adanya aliran Sungai Buyat yang bermuara di sudut Barat Laut perairan tersebut. Sedimen-sedimen asal daratan yang terbawa oleh aliran mengendap terutama di lereng dekat pantai dan di lereng-lereng bawah bercampur dengan material tailing serta sedimen-sedimen laut lainnya. Relief lokal sepanjang 1-3 m tampak lereng-lereng yang lebih terjal di perairan Buyat dan kemungkinan diakibatkan oleh erosi dan longsor laut alami (Sompie, dkk. 2001).

Kawasan perairan Teluk Buyat dan sekitarnya merupakan suatu kawasan yang dihuni oleh beberapa biota (ikan, terumbu karang maupun moluska) sebagai tempat mencari makan, berlindung maupun tempat bertelur. Namun kawasan ini akan menjadi kurang nilainya jika untuk mencari makan, berlindung maupun bertelur bagi biota di kawasan tersebut hancur atau rusak.

Ancaman terhadap degradasi habitat adalah degradasi terumbu karang. Degradasi terumbu karang di perairan pesisir disebabkan oleh berbagai aktivitas manusia, diantaranya pemanfaatan ekosistem terumbu karang sebagai sumber pangan (ikanikan karang), sumber bahan bangunan (galian karang), komoditas perdagangan (ikan hias), dan obyek wisata (keindahan dan keanekaragaman hayati). Degradasi terumbu karang akibat pemanfaatannya sebagai sumber pangan maupun ikan hias sebagian besar dikarenakan oleh penggunaan bahan peledak, tablet potas dan sianida (Bengen, 2000).

Kemudian menurut Bengen (2002) bahwa penanggulangan pencemaran yang diakibatkan oleh industri dan limbah rumah tangga, sedimentasi akibat erosi dari kegiatan perkebunan, kehutanan dan limbah pertanian tidak hanya dilakukan di kawasan pesisir saja, melainkan harus dilakukan mulai dari sumber dampaknya. Oleh karena itu, pengelolaan di wilayah ini harus diintegrasikan dengan wilayah daratan dan laut serta Daerah Aliran Sungai (DAS) menjadi satu kesatuan dan keterpaduan pengelolaan. Pengelolaan yang baik di wilayah pesisir akan hancur dalam sekejap, jika tidak diimbangi dengan perencanaan DAS yang 


\section{Kelarutan Sedimen Dalam Asam di Teluk Buyat}

baik pula. Keterkaitan antar ekosistem yang ada di wilayah pesisir harus selalu diperhatikan.

Penelitian ini dilakukan untuk mengukur kandungan sedimen yang larut dan yang tidak larut dalam asam di perairan teluk Buyat dan sekitarnya. Sehingga dengan mengetahui jumlah kandungannya, penyebabnya dapat diketahui.

Upaya pemanfaatan sumberdaya pantai akan selalu menimbulkan persilangan pendapat mengenai dampak negatif yang timbul dari pemanfaatan wilayah tersebut. Di satu ekstrim, mereka menginginkan agar wilayah pantai/pesisir tersebut bebas dari pengaruh manusia dan dibiarkan sebagaimana adanya. Di ekstrim lain, mereka ingin memanfaatkan semaksimal mungkin sumberdaya pantai yang ada tanpa menyadari kerusakan yang ditimbulkan (Pariwono, 1996).

Dijelaskan oleh Duxbury dan Duxbury (1993) sedimen sebagai kumpulan partikel-partikel organik dan anorganik yang terakumulasi secara luas dan bentuknya tak beraturan. Sekitar $70,8 \%$ permukaan bumi ditutupi oleh laut, bagian muka bumi yang sangat luas ini merupakan lingkungan tumpahan material-material sedimen yang terjadi secara fisika, kimiawi, maupun organik yang satu sama lain akan berinteraksi membentuk berbagai macam variasi sedimen (Kaharuddin, 1994). Selanjutnya Davis (1991) menyatakan sedimen yang menutupi dasar perairan memiliki berbagai variasi dalam bentuk partikel komposisi ukuran, sumber atau asal sedimen.

Dalam klasifikasi sedimen, kelompok sedimen lithogenous dan biogenous yang mendominasi daerah pantai. Sebanyak $90 \%$ dari total sedimen yang berada di daerah pantai berasal dari erosi daratan dan berupa sedimen lithogenous yang disebut klastik (Pethick, 1997). Kehadiran dari sedimen biogenous karena terumbu karang yang berkontribusi nyata pada sejumlah kawasan di daerah pantai.

Material sedimen yang terdeposisi di daerah pantai dan laut dalam dikontrol oleh dua faktor. Faktor tersebut adalah transpor material pelapukan di daratan ke laut dan transpor yang terjadi di dalam laut itu sendiri (Riley dan Chester dalam Djamaluddin, 1993). Proses pergerakan butiran sedimen menyusur pantai ditimbulkan oleh gerakan orbital gelombang yang menyebabkan sedimen bergerak bolak-balik dalam keadaan suspensi tanpa terjadi perpindahan. Terjadinya perpindahan atau pengangkutan sedimen bila ada arus yang bekerja dan arahnya mengikuti arah arus tersebut (Bagnold dalam Thornbury, 1964).

Dasar laut merupakan daerah yang luas dan pada daerah ini mengandung material skeletal. Milyaran mikroorganisme berada dan hidup pada permukaan dasar laut ini, di sini mereka berkembang, melakukan reproduksi, sampai akhirnya mati. Bagian-bagian tubuh organisme akan terakumulasi dan tersebar secara luas pada dasar laut (Ingmanson and Wallace, 1989).

Menurut Pariwono (1996), bahan organik merupakan pencemar perairan yang paling umum dijumpai dan dampak yang ditimbulkannya tidak langsung. Masalah yang ditimbulkannya adalah menurunkan kandungan oksigen terlarut dan terjadi proses eutrofikasi (proses bertumbuh-kembangnya organisme perairan karena kesuburan yang meningkat dan biasanya mempunyai dampak negatif terhadap ikan).

\section{METODE PENELITIAN}

Data yang dikumpulkan yaitu diperoleh secara langsung di daerah penelitian dengan cara observasi (pengamatan). Kegiatan yang dilakukan dalam penelitian ini adalah pengukuran sedimen dengan menggunakan sediment trap. Lokasi penelitian berada di perairan Teluk Buyat dan sekitarnya.

Dalam pengukuran sedimen dimana terlebih dahulu sudah menempatkan sediment trap pada 8 stasion, kemudian mengambilnya dengan selang waktu 1 minggu atau 2 minggu (tergantung keadaan cuaca) secara berkesinambungan. Khusus untuk stasion 3 dekat dengan muara sungai digunakan 2 buah sediment trap yaitu 1 menghadap ke laut (3A) dan satu lagi menghadap ke arah muara sungai (3B). Sediment trap yang digunakan mempunyai panjang $11,5 \mathrm{~cm}$, diameter $(\varnothing) 5 \mathrm{~cm}$ dan diletakkan $20 \mathrm{~cm}$ dari dasar. Selanjutnya penempatan sediment trap yaitu dengan menggunakan alat bantu berupa pipa diletakkan pada balok beton di permukaan dasar perairan an- 
tara koloni karang kecuali stasion 3 karena tidak ada karang. Konstruksi dari sediment trap ini mengacu pada Gardner, (1980) dalam English, et al. (1997). Selanjutnya kedalaman yang diletakkan alat ini yaitu berkisar 3-4 m.

Dalam perlakuannya sedimen yang larut dalam asam dan yang tidak yaitu sampel disaring dan dikeringkan pada oven pengering selama 3 jam dengan suhu $80^{\circ} \mathrm{C}$. Endapan yang tertinggal dilarutkan dalam larutan $\mathrm{HCl} 1 \mathrm{~N}$ (untuk membuktikan dari mana asal padatan tersebut) selama 12 jam sambil sekali-sekali dikocok, dan selanjutnya larutan yang ada disaring lagi pada filter yang sama dan dicuci lagi dengan air suling (bebas logam) secukupnya dan dipanaskan pada suhu yang sama pula kemudian ditimbang kembali. Selisih berat masing-masing dihitung sedimen total, yang larut dan yang tidak larut dalam asam.

\section{HASIL DAN PEMBAHASAN}

Berdasarkan hasil yang didapat pada pengambilan I memperlihatkan dari total sedimen yang ada menunjukkan bahwa sedimen yang diduga berasal dari daratan sedikit yang larut dalam asam jika disbandingkan dengan sedimen yang berasal dari pecahan terumbu karang atau yang sudah lama di laut dan jelasnya sebagaimana diperlihatkan pada Gambar 1.

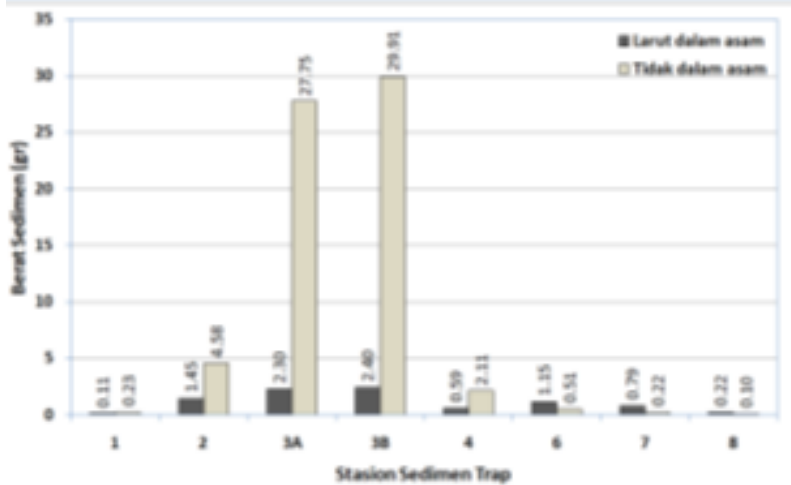

Gambar 1. Grafik sedimen yang larut dalam asam dan yang tidak larut dalam asam pada setiap stasion pengambilan I (pertama) dengan waktu 2 minggu.

Pada Gambar 1 tersebut menunjukkan bahwa perbandingan antara sedimen yang larut dalam asam jauh lebih kecil bila dibandingkan dengan sedimen yang tidak larut dalam asam, hal ini dibuktikan dengan sedimen yang terdapat pada stasion $3 \mathrm{di}-$ bandingkan dengan sedimen yang terdapat pada stasion 6 dan 7. Karena dilihat dari perbandingannya untuk total dengan yang tidak larut dalam asam cukup besar. Namun perlu juga diketahui bahwa stasion 3 memang berada dalam teluk sehingga kandungan sedimen yang berasal dari daratan cukup tinggi dan sebaliknya untuk stasion 6 dan 7 berada di luar teluk sehingga sedimennya adalah yang banyak berasal dari laut.

Untuk pengambilan II memperlihatkan jumlah total sedimen yang diperoleh menunjukkan bahwa tidak larut dalam asam lebih banyak jika dibandingkan dengan larut dalam asam sebagai contoh untuk sedimen yang berada pada stasion 3 , dan ini diduga bahwa sedimen tersebut berasal dari daratan sebaliknya seperti sedimen yang berada pada stasion 7 dan 8 dimana yang larut dalam asam lebih banyak disbandingkan dengan yang tidak larut dalam asam dan ini diduga sedimen tersebut berasal dari laut atau sedimen dari darat tetapi sudah lama berada di laut, selanjutnya berdasarkan hasil tersebut dibuatlah suatu grafik seperti pada Gambar 2.

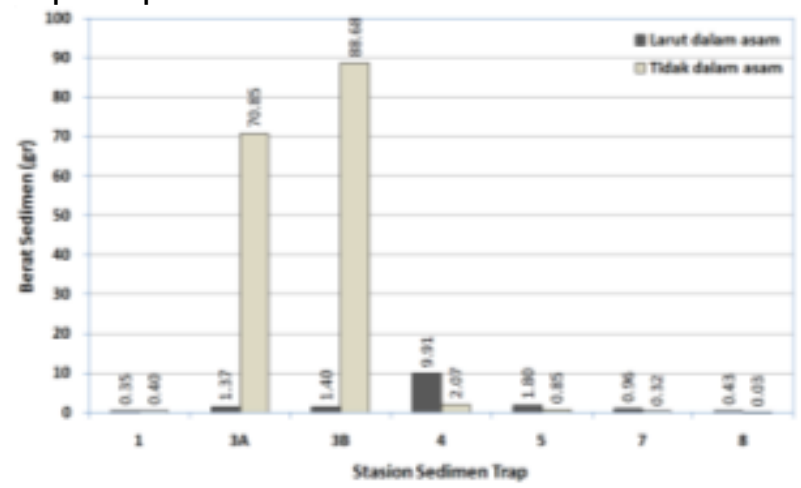

Gambar 2. Grafik sedimen yang larut dalam asam dan yang tidak larut dalam asam pada setiap stasion pengambilan II (kedua) dengan waktu 1 minggu.

Kemudian untuk pengambilan III menunjukkan bahwa sedimen pada stasion 3 yang sudah dapat dipastikan berasal dari daratan dan letaknya juga berada dekat muara sungai dan begitu juga dengan stasion 7 yang letaknya agak jauh dari muara sungai yang mengartikan bahwa material sedimen yang didapat berasal dari laut, jelasnya hasil tersebut dibuatlah suatu grafik seperti pada Gambar 3.

Pada Gambar 3 tersebut memperlihatkan bahwa sedimen yang berada di stasion 3 masih mendominasi untuk yang tidak larut dalam asam. Namun untuk stasion 1 
yang letaknya agak jauh dari muara sungai dan juga sediment trapnya berada di atas terumbu karang hal serupa juga untuk stasion 2, (tetapi stasion 2 letaknya dekat dengan teluk Buyat) tetapi dari jumlah total sedimen yang tidak larut dalam asam lebih banyak jika dibandingkan dengan yang larut dalam asam walaupun perbandingannya tidak terlalu besar, sehingga diduga bahwa sedimen yang berada di daerah tersebut berasal dari daratan lebih banyak dibandingkan dengan yang berasal dari laut, dan ini mengartikan bahwa keadaan suatu perairan tidak pernah tenang apalagi pada daerah pantai misalnya pergerakan massa air banyak dipengaruhi arus pasut maupun arus laut.

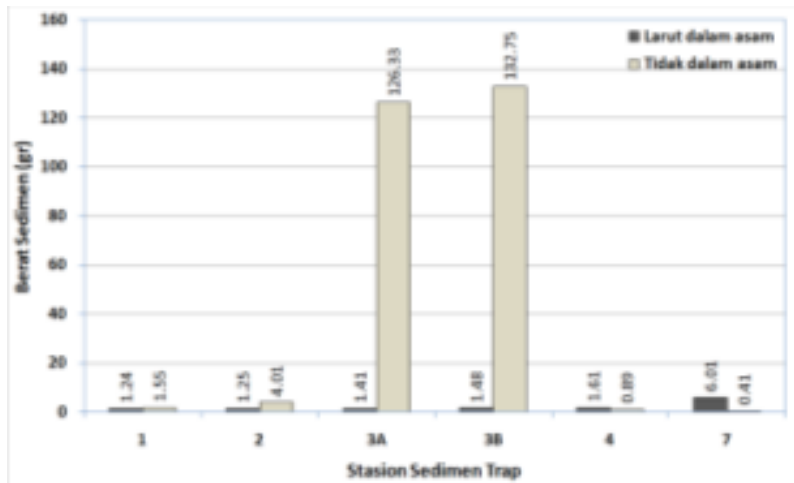

Gambar 3. Grafik sedimen yang larut dalam asam dan yang tidak larut dalam asam pada setiap stasion pengambilan III (ketiga) dengan waktu 2 minggu.

Hasil yang diperoleh pada pengambilan IV memperlihatkan bahwa masih punya kaitan dengan yang terjadi pada pengambilan sediment trap ketiga, dimana untuk pengambilan yang ke-empat ini yang mencolok yaitu pada stasion 2 masih banyak juga sedimen yang tidak larut dalam asam padahal letaknya berada di luar Teluk Buyat walaupun tidak terlalu jauh dan berdasarkan hasil yang diperoleh pada pengambilan IV dibuatlah suatu grafik seperti pada Gambar 4.

Gambar 4 memperlihatkan bahwa untuk stasion 2 sedimen yang larut dalam asam dan yang tidak larut dalam asam tidak berbeda jauh karena pada selang periode waktu tersebut kondisi perairan bergelombang dan juga terjadi hujan sehingga sedimen yang berada di dasar perairan teraduk atau terbongkar oleh adanya gelombang, begitu juga yang berasal dari daratan. Hal ini juga dibuktikan yaitu pada waktu penyelaman untuk pengambilan sediment trap selain masih bergelombang dan berarus keadaan perairan sangat keruh.

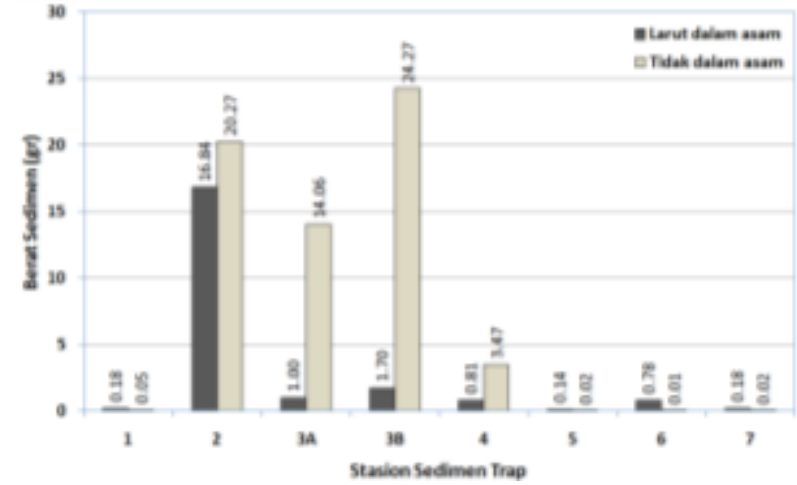

Gambar 4. Grafik sedimen yang larut dalam asam dan yang tidak larut dalam asam pada setiap stasion pengambilan IV (keempat) dengan waktu 1 minggu

Kemudian hasil yang diperoleh pada pengambilan $\mathrm{V}$ memperlihatkan bahwa dari jumlah total sedimen yang didapat menunjukkan stasion 3 dan 4 yang berada di dalam Teluk Buyat jauh lebih banyak yang tidak larut dalam asam jika dibandingkan dengan stasion yang berada di luar teluk dimana yang larut dalam asam lebih banyak (Gambar 5).

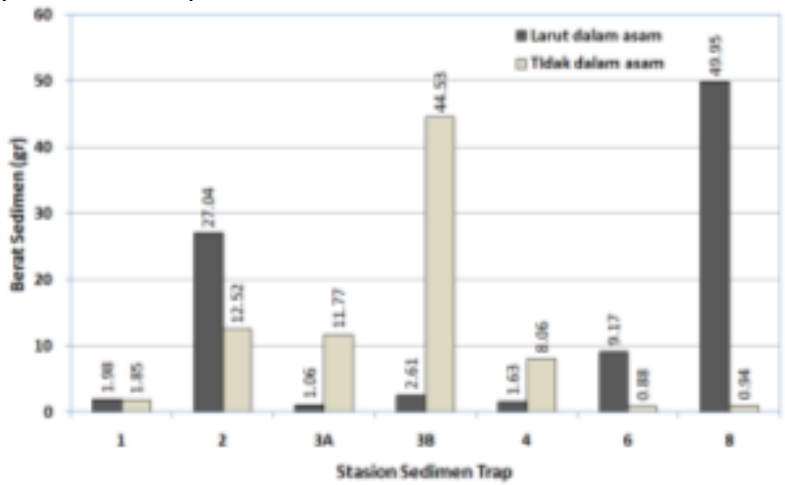

Gambar 5. Grafik sedimen yang larut dalam asam dan yang tidak larut dalam asam pada setiap stasion pengambilan V (kelima) dengan waktu 2 minggu.

Pada Gambar 5 tersebut menunjukkan bahwa untuk stasion 2 maupun 8 jumlah sedimen yang larut dalam asam jauh lebih banyak jika dibandingkan dengan stasion yang lain dan untuk diketahui bahwa sedimen yang ditemukan pada stasion 8 tersebut hampir keseluruhan asal sedimennya berasal dari bongkahan karang karena warnanya agak putih.

Berdasarkan dari hasil-hasil yang didapatkan tersebut memperlihatkan bahwa sedimen yang ditemukan pada setiap sediment trap dengan stasion jauh dari muara sungai (Teluk Buyat) terindikasi bahwa jum- 
lah material sedimen banyak berasal dari pecahan terumbu karang dan larut dalam asam, dan untuk jumlah material sedimen yang berada dekat dengan muara sungai (Teluk Buyat) jumlahnya lebih banyak yang tidak larut dalam asam (asal sedimen dari daratan).

\section{KESIMPULAN}

Sedimen yang berasal dari daratan tidak larut dalam asam, sedangkan sedimen yang berasal dari laut (terutama bongkahan karang) larut dalam asam. Bongkahan-bongkahan karang tersebut sebagai bentuk akibat dari pemboman-pemboman ikan karang serta pengambilan ikan karang dengan menggunakan bahan racun. Hal ini dengan melihat perbandingan sedimen yang larut dalam asam dan yang tidak larut dalam asam.

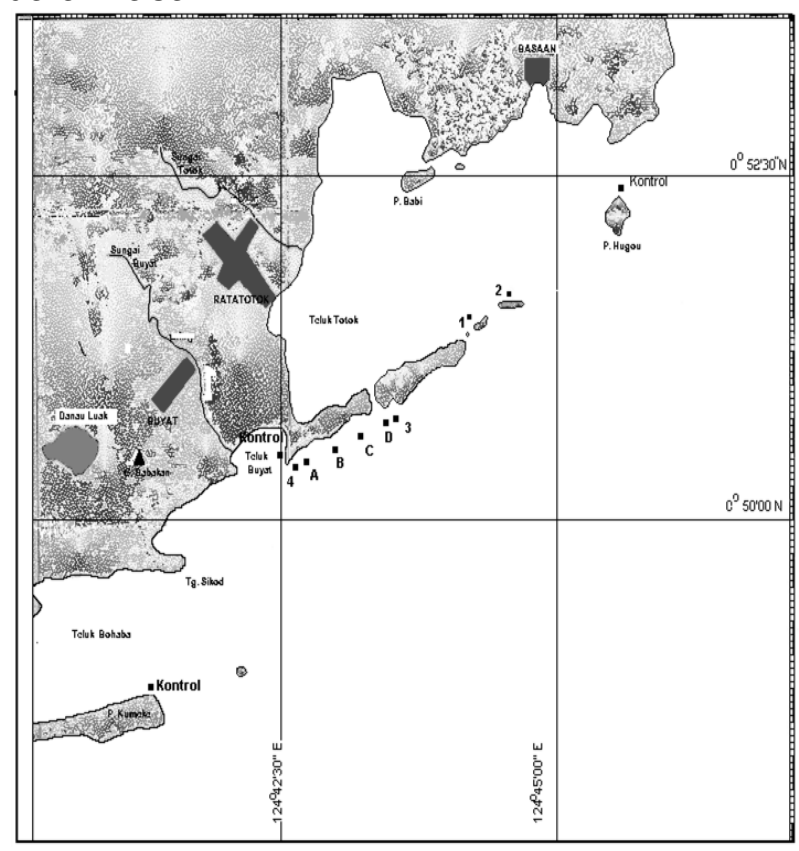

Gambar 6. Peta lokasi penelitian daerah Teluk Buyat dan sekitarnya

\section{DAFTAR PUSTAKA}

Bengen, D.G., 2000. Ekosistem dan Sumberdaya Alam Pesisir. Sinopsis. Pusat Kajian Sumberdaya Pesisir dan Lautan. Institut Pertanian Bogor.
Bengen, D.G., 2002. Konsep Pengelolaan Wilayah Pesisir Terpadu Berbasisi Ekosistem dan Masyarakat. Makalah disampaikan dalam Pelatihan Pengelolaan Wilayah Pesisir Terpadu (Manado 16-21 September 2002).

Davis Jr., A.R., 1991. Oceanography: An Introduction to the Marine Environment. Wm. C. Brown Publishers. Iowa. USA.

Djamaluddin, R., 1993. Sifat Fisika Kimia Sedimen di Laut. Tesis. Program Pascasarjana IPB. Bogor.

Duxbury, A.B. dan A.C. Duxbury, 1993. Fundamental of Oceanography. Wm. C. Brown Publ. Washington.

English, S., C. Wilkinson, and V. Baker, 1997. Survey Manual for Tropical Marine Resources ( $2^{\text {nd }}$ Edition). Australian Institute of Marine Science. Townsville.

Ingmanson, D.E. dan W.J. Wallace, 1989. Oceanography: An Introduction. $4^{\text {th }}$ edition. Wadsworth Publishing Company Belmont. California.

Kaharuddin., 1994. Marine Sediment and Preparation. Program Studi IImu dan Teknologi Kelautan, Universitas Hasanudin. Ujung Pandang.

Pariwono, J.I., 1996. Oseanografi Fisika dan Dinamika Perairan Pesisir. Materi Pelatihan Perencanaan dan Pengelolaan Wilayah Pesisir Secara Terpadu (ICZPM). PKSPLLP IPB kerjasama dengan Dirjen BANGDA-DEPDAGRI. Bogor.

Pethick, J., 1997. An Introduction to Coastal Geomorphology. Edward Arnold. London.

Sompie, D., J. Kojansow, D. Laneawicz, G. Mamuaya, 2001. Menentukan Ketebalan Pengendapan Tailing Dengan Pengukuran Bathymetry. Dipresentasikan pada Pertemuan IImiah Nasional ISOI (Jakarta 29-31 Mei 2001).

Thornbury, W.D., 1964. Principles of Geomorphology. By John Wiley and Sonc. Inc. 